Original Research Paper

\title{
Efektifitas Pelaksanaan Kurikulum 2013 ditinjau dari Kesiapan Sekolah dan Pengaruhnya terhadap Perkembangan Sekolah
}

\author{
Melkianus Suluh $^{1 *}$, Dekriati Ate ${ }^{2}$ \\ ${ }^{1}$ Program Studi Pendidikan Fisika, STKIP Weetebula, Sumba Barat Daya-NTT, Indonesia; \\ ${ }^{2}$ Program Studi Pendidikan Matematika, STKIP Weetebula, Sumba Barat Daya-NTT, Indonesia.
}

\section{Article history}

Received: May $31^{\text {th }} 2019$

Revised: July $20^{\text {th }} 2019$

Accepted: July $31^{\text {th }} 2019$

*Melkanus Suluh: Program Studi Pendidikan Fisika, STKIP Weetebula, Sumba Barat Daya-NTT, Indonesia: Email:

pplstkipweetebula@gmail.com

\begin{abstract}
This study aims to determine: (1) school readiness and response to the 2013 curriculum, (2) the effectiveness of the 2013 curriculum implementation on school development, (3) the supporting and inhibiting factors for the implementation of the 2013 curriculum in physics learning, and (4) Implementation of process standards and curriculum evaluation standards for 2013. This research is a qualitative descriptive study. The research subjects were Physics Teachers, Mathematics Teachers, and Indonesian Teachers. Research data was collected by conducting in-depth interviews. The results of the study show that: 1) the principal and teacher state the readiness for the implementation of the 2013 curriculum. 2) the application of the 2013 curriculum influences the efforts of schools to develop schools through increasing teacher human resources, providing supporting facilities and infrastructure and learning facilities; 3) supporting factors for the implementation of the 2013 curriculum are the availability of adequate teacher resources, the availability of adequate supporting facilities and infrastructure, the support of parents and the government, and the willingness of students. Meanwhile, the inhibiting factors are minimal learning media, limited student books, limited educational staff, readiness and teacher thinking methods that still use old learning patterns; 4) teachers have difficulty implementing scientific approach based learning due to lack of student enthusiasm, minimal learning media, limited laboratory and library facilities and infrastructure, for aspects of assessment teachers experience difficulties with the number of items and forms of assessment.
\end{abstract}

Keywords: 2013 curriculum; School Readiness; School Development

Abstrak: Penelitian ini bertujuan untuk mengetahui: (1) kesiapan dan tanggapan sekolah terhadap kurikulum 2013, (2) efektifitas penerapan kurikulum 2013 terhadap perkembangan sekolah, (3) faktor-faktor pendukung dan penghambat pelaksanaan kurikulum 2013 pada pembelajaran fisika, dan (4) Pelaksanaan standar proses dan standar penilaian kurikulum 2013. Penelitian ini merupakan penelitian deskriptif kualitatif. Subyek penelitian adalah Guru Fisika, Guru Matematika dan Guru Bahasa Indonesia. Data penelitian dikumpulkan dengan cara melakukan wawancara mendalam. Hasil penelitian menunjukkan bahwa: 1) kepala sekolah dan guru menyatakan kesiapan diterapkannya kurikulum 2013. 2) penerapan kurikulum 2013 berpengaruh terhadap upaya sekolah untuk mengembangkan sekolah melalui peningkatan SDM guru, penyediaan sarana dan prasarana penunjang serta fasilitas pembelajaran; 3) faktor pendukung pelaksanaan kurikulum 2013 adalah tersedianya sumber daya guru yang memadai, tersedianya sarana dan prasarana pendukung yang cukup memadai, dukungan orang tua dan pemerintah, dan kemauan peserta didik. Sedangkan, faktor penghambatnya adalah media pembelajaran yang minim, buku siswa yang masih terbatas, keterbatasan tenaga kependidikan, kesiapan dan cara berpikir guru yang masih menggunakan pola pembelajaran yang lama; 4) guru kesulitan melaksanakan pembelajaran berbasis pendekatan ilmiah disebabkan antusiasme siswa yang kurang, media pembelajaran yang minim, keterbatasan sarana dan prasaran laboratorium dan perpustakaan, untuk aspek penilaian guru mengalami mengalami kesulitan dengan banyaknya item dan bentuk penilaian.

Kata Kunci: Kurikulum 2013; Kesiapan Sekolah; Perkembangan Sekolah. 


\section{Pendahuluan}

Permasalahan pendidikan nasional hingga kini masih menjadi tantangan yang perlu mendapatkan perhatian dari berbagai pihak. Permasalahan pendidikan bukan terbatas pada upaya mewujudkan citra manusia, melainkan menyentuh hingga pada rana-rana kehidupan. Berbagai permasalahan pendidikan mulai dari prestasi pada level PISA yang rendah, merosotnya moral dan etika anak bangsa, hingga pada tantangan menyediakan sumber daya manusia yang mampu bersaing di kanca kehidupan global. Berkaiatan dengan permasalahan-permasalahan Pendidikan tersebut, Supardi (2012) pernah menyatakan bahwa perlunya pemerintah mengkaji dan mengoreksi kembali proses Pendidikan untuk sehingga arah kebijakan Pendidikan untuk menghasilkan sumber daya manusia yang ungul dapat tercapai.

Menyikapi permasalahan tersebut, pemerintah melakukan pembenahan dalam sistem pendidikan yang diinisiasi dari diterapkannya UU SISDIKNAS tahun 2003 (DEPDIKNAS, 2003), penetapan standar nasional pendidikan, hingga perubahan kurikulum. Pada tahun 2013, pemerintah mulai menerapkan kurikulum 2013 yang merupakan perbaikan dari kurikulum 2004 dan kurikulum 2006. Selain perubahan pada elemen pembelajaran, muatan kurikulum, perubahan lain pada kurikulum 2013 adalah pada konsep susunan delapan standar pendidikan, terutama pada 4 standar pertama. Susunan standar pada kurikulum 2013 diawali dengan penentuan standar komptensi lulusan, standar isi, standar proses dan standar penilaian. Berdasarkan urutan tersebut, dapat diketahui bahwa setiap lulusan memiliki kompetensi baik sikap, pengetahuan dan keterampilan sesuai jenjang pendidikannya. Berdasarkan isi kurikulum, dapat diketahui bahwa kurikulum 2013 merupakan kurikulum berkarakter dan berkemampuan akademik tinggi. Hal ini dapat kita ketahui dari muatan kurikulum yang terdiri dari 4 kompetensi inti yang memuat sikap, keterampilan dan pengetahuan. Konsep inilah yang kemudian menjadi kekuatan dan keunggulan dari kurikulum 2013.

Perubahan kurikulum dalam dunia pendidikan bukan merupakan suatu hal baru, melainkan merupakan sebuah siklus yang harus dilaksanakan mengingat tuntutan terhadap dunia pendidikan untuk mampu menyesuaikan dengan perkembangan ilmu pengetahuan dan teknologi serta tantangan jaman. Menurut Machali (2014), kebijakan perubahan kurikulum dengan diterapkkannya kurikulum 2013, didasarai pada tantangan internal dan eksternal dalam rangka menhasilkan generasi emas bangsa Indonesia.
Perubahan-perubahan dan pembenahan kurikulum dengan berbagai penyempurnaan yang dilakukan, tentu berdampak pada proses pelaksanaan pendidikan di sekolah. Guru merupakan subyek yang langsung dihadapkan pada kurikulum yang baru, sehingga guru merupakan instrumen utama yang mampu mewujudkan keberhasilan penerapan dari elemen-elemen perubahan. Sehingga tantangan awal yang dihadapi adalah bagaimana merubah pola pikir dan paradigma pembelajaran yang dimiliki guru. Berbagai upaya dilakukan Pemerintah mulai dari melaksanakan kegiatan sosialisasi, workshop, pelatihan, hingga penerapan kurikulum secara bertahap pada setiap jenjang pendidikan. Selain itu, keberhasilan kurikulum menurut Anwar (2014) ditentukan oleh seluruh pemangku kepentingan dibidang Pendidikan, terutama pada tingkat operasional dengan sikap terbuka dan mempersiapkan diri dengan model operasional yang baru. Dampak positif diterapkannya kurikulum 2013 disampaikan oleh Subkhan dan Susilowati (2015), bahwa implementasi kurikulum 2013 berdampak positif terhadap pengelolaan pembelajaran khusunya pada mata pelajaran IPA.

Berkaitan dengan penerapan kurikulum 2013, sekolah merupakan lembaga terdepan pelaksana kurikulum. Sekolah merupakan "bangunan atau lembaga untuk belajar dan mengajar serta tempat menerima dan memberi pelajaran" (KBBI). Artinya sebagai sebuah lembaga pendidikan, berhasil tidaknya kurikulum juga dipengaruhi penerimaan dan kesiapan sekolah. Sekolah merupakan lembaga yang, menjebatani terjadinya interaksi antara pendidik dan peserta didik. Interaksi belajar mengajar akan terlaksana dengan baik manakala sekolah mampu menyediakan berbagai fasilitas pendukung terjadinya interaksi pembelajaran tersebut. Sehingga ketersediaan sarana prasarana, pendidik, dan tenaga kependidikan merupakan satu kesatuan yang saling menguatkan pencapaian tujuan pendidikan nasional. Berdasarkan uraian tersebut, peneliti tertarik untuk melaksanakan penelitian tentang kurikulum 2013. Penelitian ini berjudul "Efektifitas Pelaksanaan Kurikulum 2013 Ditinjau Dari Kesiapan Sekolah Dan Pengaruhnya Terhadap Perkembangan Sekolah”.

\section{Metode}

Penelitian ini merupakan penelitian deksriptif dengan menggunakan pendekatan kualitatif. Penelitian deksriptif adalah penelitian yang mencoba mendeskripsikan suatu fenomena yang teerjadi (Sukmadinata, 2012), Sedangkan pendekatan kualitatif merupakan suatu bentuk 
pendekatan yang digunakan peneliti untuk memperoleh data penelitian. Penggunaan pendekatan kualitatif ditujukan untuk memperoleh data secara mendalam dimana peneliti merupakan instrumen utama.

Penelitian ini dilaksanakan di SMP dan SMA yang terdapat di Kecamatan Loura dan kecamatan Kota Tambolaka Kabupaten Sumba Barat DayaNTT yang merupakan mitra PPL STKIP Weetebula. Penelitian dilakukan sejak bulan Agustus sampai bulan November 2018. Jumlah Sekolah yang Menjadi sumber data dalam penelitian ini 6 SMP dan 6 SMA dengan total subyek penelitian adalah 12 Kepala Sekolah, dan 36 guru, yang terdiri dari 12 guru fisika, 12 guru matematika, dan 12 guru Bahasa Indonesia. Obyek penelitian ini adalah penerapan Kurikulum 2013.

Teknik pengumpulan data yang digunakan dalam penelitian ini adalah teknik wawancara dengan menggunakan panduan instrumen wawancara semi terstruktur. Dalam pengumpulan data, peneliti merupakan instrumen utama dibantu oleh beberapa mahasiswa yang telah dilatih untuk melaksanakan wawancara mendalam. Pedoman wawancara sebelum digunakan terlebih dahulu di uji valid dengan menggunakan validitas konten dan konstruk. Sedangkan teknik analisis data yang digunakan adalah teknik analisis yang dikembangkan oleh Miles dan Huberman (Sugiyono, 2008), yakni tahap reduksi data (data reduction), penyajian data (data display), dan penarikan kesimpulan/verifikasi (conclusion drawing/verification).

\section{Hasil dan Pembahasan}

Penelitian ini secara umum hendak mengkaji penerapan kurikulum 2013 di SMP/SMA dengan memperhatikan faktor-faktor yang saling terkait, yakni kesiapan sekolah, ketersediaan sarana prasarana, sumber daya pendidik, efektifitas penerapan dalam pembelajaran, faktor pendukung, dan faktor penghambat tercapainya tujuan utama dari kurikulum 2013.

\section{Kesiapan dan Tanggapan Sekolah}

Sekolah merupakan institusi terdepan yang memiliki peran strategis dalam mewujudkan terlaksananya berbagai kebijakan pendidikan, serta sekaligus sebagai lembaga yang mewadahi para eksekutor-eksekutor pendidikan, sehingga tercapai tidaknya suatu kebijakan pendidikan sangat ditentukan kesiapan dan penerimaan sekolah. Sebagai sebuah lembaga, kesiapan dan penerimaan sekolah perlu dilihat secara utuh tidak sebatas pada unsur pimpinan, melainkan keseluruhan komponen yang saling terkait (pendidik dan SDM pendidik, tenaga kependidikan, sarana-prasarana, dan peserta didik). Menurut KBBI, sekolah adalah "bangunan atau lembaga untuk belajar dan mengajar serta tempat menerima dan memberi pelajaran". Dari pengertian tersebut jelas terlihat bahwa sekolah bukan sebatas gedung/ruang belajar, namun sekolah juga berkaitan dengan siapa yang belajar dan siapa yang membelajarkan, dan tentunya kepala sekolah yang berfungsi sebagai leader dan manajer, sehingga berkaitan dengan penelitian ini, kesiapan sekolah merupakan kesiapan dari unsur kepala sekolah, guru, sarana dan prasarana, serta tenaga pendidikan.

Hasil penelitian secara umum memberikan gambaran pada umumnya sekolah sangat siap untuk menerapkan kurikulum 2013. Bentuk kesiapan sekolah dalam mempersiapkan hingga menerapkan kurikulum 2013 adalah dengan senantiasa melibatkan guru dalam kegiatan-kegiatan yang berkaitan dengan kurikulum 2013, baik yang diselenggarakan Dinas Pendidikan Kabupaten, maupun tingkat Propinsi dan tingkat nasional. Selain itu bentuk dukungan sekolah terhadap penerapan kurikulum 2013adalah melaksanakan workshop ditingkat sekolah, dan memperoleh pendampingan dari sekolah pembina (Sekolahsekolah Pilot Project).

Selain menyiapkan SDM pendidik, sekolah juga juga berusaha meningkatan ketersediaan sarana dan prasarana penunjang berupa perpustakaan, laboratorium, dan kebutuhan media pembelajaran lainnya. Namun dengan keterbatasan sumber daya angaran yang dimiliki sekolah, penyediaan sarana-prasarana dan fasilitas pendukung lainnya harus dipenuhi secara bertahap. Terkait dengan media pembelajaran, sekolah lebih banyak mengharapkan kreatifitas dan daya juang dari guru untuk menyiapkan sendiri bahan-bahan yang dibutuhkan. Berdasarkan hasil penelitian, secara umum kesiapan sekolah dari sisi ketersediaan sarana dan prasarana dapat dikatakan belum maksimal. Hal ini telihat dari banyaknya sekolah sekolah yang belum memiliki fasilitas sarana dan prasarana pendidikan yang memadai. Permasalahan sarana dan prasarana juga diungkapkan oleh Kristiantari (2014) bahwa guru memiliki motivasi yang sangat tinggi namun penerapan kurikulum 2013 masih terkendala dengan ketersediaan sarana dan prasarana penunjang. Permasalahan yang yang ditemukan dalam penelitian-penelitian tersebut, sejalan dengan dengan tantangan internal pengembangan kurikulum 2013, yakni pemenuhan delapan standar pendidikan nasional yang meliputi standar pengelolaan, pembiayaan, sarana prasarana, pendidik dan tenaga kependidikan, standar isi, 
standar proses, standar penilaian, dan standar kompetensi lulusan (Kemendikbud 2011, dan 2013). Pentingnya sarana dan prasarana juga disampaikan oleh Sutama, et al., (2016) bahwa "kelengkapan sarana prasarana pendidikan secara parsial memberikan kontribusi terhadap kinerja guru, sebab, sarana dan prasarana pendidikan dapat menjadi pendukung faktor-faktor lain yang lebih dominan dan mampu membuat kinerja guru dapat meningkat".

Berkaitan dengan penerapan kurikulum 2013 secara penuh, Sekolah memberikan respon yang sangat positif. Sekolah menyadari bahwa pemberlakukan kurikulum 2013 merupakan sebuah kebutuhan pendidikan. Sekolah memiliki pandangan bahwa kurikulum 2013 memiliki karakter yang berbeda dengan kurikulum sebelumnya. Kurikulum 2013 dipandang memberikan suasana pendidikan yang baru, dimana siswa menjadi subyek pembelajaran, peserta didik tidak lagi sebatas menerima pelajaran dari guru, namun peserta didik dapat mencari, menemukan dan memanfaatkan berbagai sumber belajar. Selain itu disampaikan bahwa kelebihan lain dari kurikulum 2013 adalah adanya buku guru dan buku siswa, baik yang tersedia dalam bentuk hard copy maupun soft copy.

Pada aspek penilaian, sekolah memberikan penilaian bahwa kurikulum ini memberikan efek positif terhadap peningkatan bakat dan keeterampilan peserta didik, karena penilaian tidak difokuskan pada aspek pengetahuan saja. Hal menarik lainnya adalah kurikulum 2013 terlihat lebih komplit karena mengangkat empat kompetensi inti yang pada dasarnya sangat sesuai dengan Pancasila, Bhineka tunggal ika dan karakter bangsa Indonesia, yakni terdapat kompetensi inti yang berkaitan dengan norma keagaamaan, moral pancasila, sikap, pengetahuan dan keterampilan. Kompetensi-kompetensi inti tersebut dinilai oleh sebagai keunggulan dan sudah seharusnya ada dalam pendidikan Indonesia.

Berkaitan penerapan kurikulum 2013, sedikit disoroti pada perubahan susunan mata pelajaran, bila pada kurikulum sebelumnya terdapat mata pelajaran komputer, pada kurikulum 2013 mata pelajaran komputer ditiadakan. Hal ini dikatakan sedikit bertentangan dengan tuntutan kurikulum yang menghendaki agar proses pendidikan lebih banyak menggunakan internet dan komputer. Selain itu, dijelaskan bahwa hal ini juga berpengaruh terhadap pelaksanaan Ujian Nasional (UN) berbasis komputer, sekolah harus berupaya memberikan bimbingan tambahan agar saat pelaksanaan ujian, peserta didik mampu mengoperasikan komputer dalam menentukan jawaban yang tertera dilayar komputer.

\section{Efektifitas Penerapan Kurikulum 2013 Terhadap Perkembangan Sekolah}

Penerapan kurikulum seyogyanya dapat meningkatkan kualitas pendidikan secara menyeluruh, baik terhadap peserta didik, pendidik, maupun sekolah sebagai wadah pendidikan, sehingga pada akhirnya kualitas sumber daya manusia Indonesia yang berkemampuan akademik tinggi, kreatif dan terampil, serta memiliki sikap yang berkerakter Pancasila dapat tercapai. Hasil penelitian memberikan gambaran bahwa penerapan kurikulum 2013 selain berdampak positif terhadap perkembangan belajar peserta didik, juga berdampak positif terhadap peningkatan keprofesionalan pendidik.

Efektitas penerapan kurikulum 2013 terhadap peningkatan kualitas pendidik dapat diketahui upaya guru untuk memahami, dan menerapkan kurikulum secara masksimal. Kepala sekolah menyatakan bahwa dengan diterapkannya kurikulum 2013, dengan sendirinya guru berusaha meningkatkan pengetahuan dan keterampilan. Guru menjadi lebih tertantang karena kurikulum 2013 mengarah pada pencapaian Standar Kompetensi Lulusan (SKL). Setiap usaha guru harus senantiasa mengarah kepada pencapaian Standar Kompetensi Lulusan melalui pencapaian kompetensi inti dan kompetensi dasar. Disampaikan bahwa bila pada kurikulum sebelumnya guru dapat menghindari materi-materi yang dianggap sulit, maka pada kurikulum 2013 hal tersebut tidak dapat dilakukan. Tuntutan tersebut dengan sendirinya memacu guru untuk meningkatkan pengetahuan dan keterampilan, yang pada akhirnya meningkatkan profesionalisme guru. Selain itu, kurikulum 2013 juga mendorong guru untuk lebih menguasai IT dan memanfaatkan komputer, sehingga tidak ada lagi dikemudian hari guru yang tidak menguasai IT. Poin lain yang menjadi kelebihan dari kurikulum 2013 ini disebutkan adalah guru memiliki kesempatan untuk melakukan evaluasi, apakah proses pembelajaran yang dilaksanakan telah mencapai standar yang ditetapkan, bila belum tercapai, maka guru memiliki kesempatan untuk memperbaiki melalui kegiatan remerdial dan melakukan pengayaan terhadap peserta didik yang memiliki kecepatan belajar.

Efektifitas kurikulum 2013 terhadap peserta didik yakni memberikan pengaruh terhadap perkembangan perkembangan belajar peserta didik. Kurikulum 2013 memberikan kesempatan kepada peserta untuk menggali, dan menemukan pengetahuan sendiri melalaui kegiatan pembelajaran yang bersifat scientific. Proses pembelajaran tidak lagi berpusat di kelas melainkan dapat dilaksanakan dilingkungan sekitar, di laboratorium dan peserta didik dapat 
memanfaatakan internet dan media sekitar untuk mendaptkan pengetahuan. Namun dikatakan tantangan terbesar dari kegiatan tersebut adalah terbatasnya sarana dan prasaran yang dimiliki sekolah.

Selain aspek pengetahuan, dikatakan bahwa kurikulum 2013 juga memberikan kesempatan kepada peserta didik untuk mengembangkan keterampilan dan sikap. Disampaikan untuk mendukung peningkatan keterampilan, selain pembelajaran yang berbasis laboratorium dan eskperimen/percobaan, sekolah mencoba memfasilitasi peserta didik melalui kegiatan ekstrakurikuler dan intrakurikuler. Dengan adanya penilaian terhadap aspek keterampilan, disampaiakn bahwa penilaian tersebut memberikan ruang bagi peserta didik untuk menutupi kekurangan dari aspek pengetahuan.

Efektifitas penerapan kurikulum 2013 terhadap sekolah dapat dilihat dari perkembangan sekolah sebagai sebuah lembaga. Penerapan kurikulum 2013 memberikan kesempatan kepada sekolah untuk berbenah dalam menyediakan sumber daya pendidikan yang profesional, juga berusaha menyediakan sarana dan prasarana yang dapat menunjang terlaksananya kurikulum 2013 dengan baik. Hasil wawancara juga menunjukkan bahwa dalam upaya meningkatkan pemahaman guru terhadap kurikulum 2103, sekolah menyatakan selalu mengutus guru bila terdapat pelatihan dan workshop, demikian juga dengan kegiatan-kegiatan lain yang berkaitan dengan pengembangan profesional guru. Sedangkan pada aspek penyediaan sarana dan prasarana, sekolah berusaha memanfaatkan sumber daya yang ada, dan mendorong guru-guru, agar kegiatan pembelajaran yang bersifat scientific dapat tetap dilaksanakan dengan memanfaatakan sumber daya yang ada, dan yang mampu disediakan oleh guru dan peserta didik.

Berdasarkan hasil penelitian, diketahui bahwa penerapan kurikulum 2013 dan tuntutan pengiringnya berkontribusi positif terhadap peningkatan profesionalisme guru. Guru dengan sendirinya berupaya menyesuaikan tuntutan dan kebutuhan kurikulum. Dampak positif kurikulum 2013 terhadap peserta didik adalah diungkapkan oleh Sutjipto (2014) dan Rahayu (2016), bahwa kurikulum 2013 berpengaruh terhadap perkembangan sikap, pengetaHuan dan keterampilan peserta didik.

\section{Faktor Pendukung Keberhasilan Kurikulum 2013}

Keberhasilan kurikulum 2013 tidak hanya ditentukan oleh sempurnahnya kurikulum 2013 dari aspek muatan, tujuan, sasaran, dan metode pencapaian. Guru dan Kepala Sekolah yang menjadi subyek penelitian menyampaikan beberapa faktor yang dapat menunjang keberhasilan kurikulum 2013.

Pertama, tersedinya sumber daya pendidik yang memadai, yakni guru-guru yang mengajar memiliki latar belakang pendidikan yang memadai, yakni Strata Satu (S1) yang sesuai dengan bidang ilmu. Dalam upaya meningkatkan layanan dan mutu pendidikan terhadap peserta didik, sekolah berupaya menyediakan tenaga pendidik yang berkualifikasi minimal dan sesuai dengan bidang ilmu/bidang studi yang diajarkan.

Kedua, tersedinya ruang kelas yang memadai. Untuk meningkatkan layanan terhadap siswa dalam kegiatan belajar mengajar, sekolah berusaha memaksimalkan ruang belajar dengan menyesuaikan ruang kelas dan jumlah peserta didik sesuai aturan yang telah jumlah peserta didik pada setiap rombongan belajar. Dengan cara tersebut sekolah dapat memberikan pelayanan belajar secara maksimal terhadap peserta didik.

Ketiga, sekolah memiliki sarana dan prasarana olahraga. Sarana dan prasaran olahraga telah menjadi salah kebutuhan sekolah dalam upaya memberikan kesempatan kepada peserta didik untuk mengembangkan bakat dan kreatifitas khususnya dalam bidang olahraga. Ketersediaan sarana prasarana olahraga juga dapat meningkatkan antusiasme peserta didik untuk bersekolah dan mengembangkan bakat yang dimiliki.

Keempat, sarana dan Prasarana Laboratorium. Laboratorium telah menjadi salah salah satu kebutuhan pokok bagi sekolah, mengingat kurikulum 2013 mengedepankan pembelajaran yang bersifat aktivitas peserta didik melalui kegiatan ilmiah. Kegiatan ilmiah menuntut terlaksananya pembelajaran yang memberikan ruang kepada peserta didik untuk terlibat melalui kegiatan pengamatan, eksperimen atau percobaan, sehingga disebutkan bahwa laboratorium dan perlengkapannya menjadi salah satu sarana yang harus dimiliki sekolah bila menghendaki terlaksananya kurikulum 2013 dengan maksimal. Namun beberapa sekolah yang belum memiliki fasilitas tersebut, baik gedung, dan sarana pendukung, melaksanakan kegiatan praktimum di kelas dengan menyediakan alat bahan dan bahan yang bisa diperoleh dan yang bisa disediakan oleh guru dan peserta didik.

Kelima, dukungan orang tua dan masyarakat. Dukungan orang tua dan masyrakat dijelaskan sangat berpengaruh terhadap optimalnya pelaksanaan kurikulum 2013. Orang tua memiliki peran dalam memberikan motivasi dan dorongan terhadap anak untuk bersekolah, menyediakan kebutuhan anak, dan mendukung program-program 
pendidikan yang dilaksanakan sekolah, sedangkan dukungan masyarakat bermanfaat dalam memberikan fungsi control terhadap perkembangan sekolah.

Keenam, perhatian pemerintah terhadap sekolah. Perhatian pemerintah yakni bagaimana usaha pemerintah melaksanakan pemerataan pendidikan, dan yang khususnya berkaitan dengan kurikulum, bagaimana pemerintah memberikan perhatian terhadap sekolah dalam melengkapi sarana dan prasarana pendukung dan meningkatkan kualitas pendidik melalui pelatihan, worshop, dan pemberian beasiswa untuk meningkatkan kemampuan akademik pendidik.

Ketuju, kemauan dari peserta didik. Peserta didik disebutkan adalah faktor utama dan faktor tujuan dari kurikulum, sehingga daya minat, kemauan dan usaha dari peserta didik pada akhirnya menjadi faktor akhir penentu dari berhasil tidaknya penerapan kurikulum 2013. Sehingga dikatakan guru perlu secara perlahan dan kontinyu dalam membimbing peserta didik untuk belajar dan menyesuaikan dengan tuntutan pendidikan.

\section{Faktor Penghambat Keberhasilan Kurikulum 2013}

Penelitian ini juga berupaya menemukan faktor-faktor yang dapat mempengaruhi keberhasilan penerapan kurikulum 2013. Berikut adalah data hasil wawancara yang dilakukan terhadap Guru dan Kepala Sekolah tentang faktorfaktor yang dapat menghambat keberhasilan kurikulum 2013.

Pertama, ketersediaan media pembelajaran yang minim. Guru harus berupaya memenuhi sendiri, dan menyesuaikan dengan kebutuhan kurikulum.

Kedua, keterbatasan buku siswa. Akibat terbatasnya buku siswa, sekolah tidak mengijinkan peserta didik untuk membawa pulang buku, atau buku hanya sekedar dipinjamkan saat jam pembelajaran, sehingga hal ini turut berpengaruh terhadap kemampuan siswa. Kekurangan ini berakibat peningkatan aktifitas siswa di kelas menjadi kurang maksimal.

Ketiga, ketersediaan tenaga kependidikan. Banyak sekolah yang belum memiliki tenaga kependidikan, terutama laboran. Selama ini, laboran dirangkap oleh guru mata pelajaran, sehingga hal berpengaruh terhadap layanan terhadap peserta didik, pengaturan penggunaan laboratorium, perawatan alat-alat laboratorium, dan inventarisasi. Guru yang merangkap laboran akan kesulitan melaksanakan semua itu, karena seharusnya laboran harus selalu berada di laboratorium menyiapkan dan menyediakan kebutuhan pengunaan laboratorium.
Keempat, kesiapan dan cara berpikir guru. Kesiapan guru yang dimaksud adalah bagaimana guru merubah pola pikir yang lama, dan menyesuaikan dengan tuntutan kurikulum yang baru. Masih banyak guru yang nyaman dengan pola pembelajaran sebelumnya, selain itu, terdapat guru yang kurang menguasai komputer.

Kelima, biaya yang minim. Anggaran yang minim menyebabkan sekolah kesulitan untuk melaksanakan Wokshop terutama dalam menghadirkan narasumber. Selain itu, Sekolah juga kesulitan dalam melengkapi kebutuhan saran dan prasarana penunjang, terutama yang berkaitan dengan kelengkapan sarana dan prasaran laboratorium.

\section{Standar Proses dan Standar penilaian}

Kurikulum 2013 sebagaimana yang dikembangkan, terdapat empat standar yang mengalami penyesuaian, yakni standar kompetensi lulusan, standar isi, standar proses dan stadar penilaian. Dari keempat standar tersebut, standar proses dan standar penilaian merupakan dus standar yang langsung dihadapi oleh pendidik dalam upaya mencapai standar isi dan standar kompetensi lulusan. Berdasarkan hasil wawancara, kedua standar tersebut mendapatkan penilaian yang berbeda dari guru, yakni guru-guru setuju dengan bentuk dan proses pembelajaran yang ditetapkan oleh Kurikulum 2013. Guru-guru menyatakan bahwa metode, dan pendekatan yang digunakan menarik, karena memberikan ruang bagi peserta didik untuk lebih aktif, meningkatkan aktifitas peserta didik, menuntut peserta didik untuk belajar mencari dan menemukan sendiri gagasan dari setiap topik/materi, memberikan tantangan kepada guru untuk mempersiapkan bentuk pembelajaran, menyediakan media pembelajaran yang sesuai, meningkatkan kemampuan guru terhadap penguasaan komputer, serta guru tertantang untuk keluar dari bentuk pembelajaran yang menempatkan guru sebagai pusat pembelajaran. Hal menarik lainnya yakni terdapat Kompetensi yang menekankan pada pembentukan karakter peserta didik. Namun dari kelebihan-kelebihan tersebut, terdapat beberapa hal yang menjadi perhatian guru, yakni terbatasnya sarana dan prasarana penunjang. Disampaikan bahwa peserta didik akan kurang aktif bilamana tidak terdapat buku siswa, atau buku siswa yang terbatas, media pembelajaran yang terbatas, laboratorium yang kurang. Selain itu, para guru merasa kesulitan melaksanakan penilaian, karena jenis, dan bentuk penilaian disampaikan oleh guru rumit dan kompleks. Bentuk dan jenisjenis penilaian tersebut, semakin terasa sulit bilamana guru dihadapkan pada jumlah peserta didik yang banyak. Berkaitan dengan permasalahan 
penilaian tersebut, penelitian yang dilakukan Ruja dan Sukanto (2015) juga menemukan permasalahan yang sama, yakni "guru masih kesulitan dalam melaksanakan penilaian atau evaluasi". Setiadi (2016) kemudian mengusulkan untuk menyederhanakan pedoman penilaian yang diikuti dengan sosialisasi dan pelatihan-pelatihan. Hal yang sama juga disampaikan oleh Kustijono \& Wiwin (2014) bahwa guru belum dapat melaksanakan "penilaian sesuai standar penilaian terutama: bagaimana cara mengembangkan instrumen penilaian yang sesuai dengan kaidah, dan bagaimana cara mengembangkan rubrik penilaian dari instrumen yang dikembangkan tersebut".

Secara umum, para guru mengatakan bahwa kurikulum 2013 memiliki konsep yang sangat baik, namun penerapan kurikulum ini perlu didukung oleh sarana dan prasarana yang memadai, mengingat kurikulum 2013 adalah kurikulum yang berbasis penemuan, scientific, dan mengarah pada pembentukan karakter, serta mengedepankan berbagai bentuk penilaian sehingga peserta didik memiliki kesempatan mengeksplorasi kemampuan, keterampilan, dan pengetahuan yang mereka miliki. Sehingga dapat disimpulkan bahwa kurikulum 2013 memiliki daya tarik baik dari sisi proses maupun penilaian. Dengan keterbatasan sarana dan prasarana penunjang, guru-guru senantiasa berusaha agar kurikulum 2013 dapat terlaksana secara maksimal. Namun hal menarik yang ditemukan dalam penelitian ini adalah terdapat istilah casingnya kurikulum 2013, pelaksanaannya KTSP.

Ketika diselidiki lebih jauh pernyataan tersebut disampaikan karena banyaknya tantangan pembelajaran dan penilaian yang dialami guru. Pertama, pada aspek pembelajaran, guru dihadapkan pada tantangan kurang purnahnya pengetahuan guru akan proses pembelajaran sebagaimana yang dikehendaki kurikulum. Kondisi tersebut terjadi manakalah sistem dan mekanisme pelatihan yang diikuti tidak menyentuh hingga pada aspek keterampilan melaksanakan pembelajaran, pelatihan lebih pada penyampian teori dan materi kurikulum. Kedua, guru dihadapkan pada kondisi sarana dan prasarana yang kurang, buku siswa yang terbatas sehingga tidak bisa dibawah pulang oleh peserta didik, dan hal ini berimbas pada pelaksanaan proses pembelajaran yang tidak memungkinkan terlaksananya pendekatan ilmiah secara maksimal. Ketiga, guru dihadapkan pada banyaknya item penilaian, dan kurangnya pengetahuan menyusun instrumen penilaian, sehingga jenis-jenis penilaian yang dibuat dapat saling terhubung dalam menjawab tutuntan yang terdapat dalam kompetensi dasar.

\section{Kesimpulan}

Berdasarkan hasil penelitian dan pembahasan tersebut, maka dapat disimpulkan bahwa: Pertama, secara umum sekolah siap dalam menerapkan dan melaksanakan kurikulum 2013 mengingat perubahan kurikulum merupakan program nasional dalam upaya memperbaiki mutu pendidikan dan meningkatkan kualitas kompetensi lulusan. Sekolah juga secara umum memberikan respon yang baik diberlakukannya kurikulum 2013 secara penuh. Kedua, penerapa kurikulum 2013 juga berpengaruh positif terhadap perkembangan sekolah, yakni adanya upaya sekolah meningkatkan kompetensi sumber daya pengajar dan secara bertahap berusaha memenuhi kebutuhan sarana prasarana dan fasilitas pendukung lainnya. Ketiga, terdapat beberapa faktor utama pendukung keberhasilan kurikulum 2013, namun dibutuhkan pengelolaan dan komitmen bersama untuk secara maksimal menyuskseskan penerapan kurikulum 2013. Faktor-faktor penghambat akan dapat diatasi bilamana sekolah mampu memaksimalkan faktorfaktor pendukung yang ada dan berupaya meminimalisir faktor-faktor yang dapat menghambat keberhasilan dari kurikulum 2013. Keempat, standar proses dan standar penilaian merupakan satu kesatuan dari suatu kegiatan belajar mengajar. Sebagaimana kurikulum 2013 merupakan kurikulum penyempurnaan dari kurikulum KTSP, maka standar proses dan standar penilaian pada kurikulum 2013 hendaknya dapat diterapkan sesuai arahan kurikulum 2013.

\section{Daftar Pustaka}

Anwar, R. 2014. Hal-Hal Yang mendasari Penerapan Kurikulum 2013. Jurnal Humaniora, 5(1), 97-106. Retrieved from https://journal.binus.ac.id/index.php/Humani ora/article/view/2987

Depdiknas. 2003. Undang-Undang Republik Indonesia Nomor 20 Tahun 2003, Tentang Sistem Pendidikan Nasional.

Kristiantari, M, R. 2014. Analisis Kesiapan Guru Sekolah Dasar dalam Mengimplementasikan Pembelajaran Tematik Integratif Menyongsong Kurikulum 2013. e-Journal Undiksa. 3(2), 460-470. Retrieved from https://ejournal.undiksha.ac.id/index.php/JPI/ article/view/4462

Kustijono, R., \& Wiwin, H, M, E. 2014. Pandangan Guru Terhadap Pelaksanaan Kurikulum 2013 
Dalam Pembelajaran Fisika SMK Di Kota Surabaya. Jurnal Pendidikan Fisika dan Aplikasinya (JPFA). 4 (1). Retrieved from https://journal.unesa.ac.id/index.php/jpfa/arti cle/view/180

Kemendikbud. 2011. Naskah Akademik Pengembangan Kurikulum. Jakarta: Kemendikbud.

Kemendikbud. 2013. Materi Pelatihan Guru Implementasi Kurikulum 2013 SMP/MTS Ilmu Pengetahuan Alam (Modul Pelatihan Implementasi Kurikulum 2013). Jakarta: Kemendikbud.

Machali, I. 2014. Kebijakan Perubahan Kurikulum 2013 dalam Menyongsong Indonesia Emas Tahun 2045. Jurnal Pendidikan Islam. 3(1).

Permendikbud. 2013. Peraturan Menteri Pendidikan dan Kebudayaan Nomor 69 tahun 2013 Tentang Kerangka Dasar Dan Struktur Kurikulum Sekolah Menengah Atas/Madrasah Aliyah. Jakarta: Kemendikbud.

Permendikbud. 2016. Peraturan Menteri Pendidikan dan Kebudayaan Nomor 22 Tahun 2016 Tentang Standar Proses Pendidikan Dasar dan Menengah. Jakarta: Kemendikbud.

Permendikbud. 2016. Tentang Kompetensi Inti Dan Kompetensi Dasar Pelajaran Pada Kurikulum 2013 Pada Pendidikan Dasar Dan Pendidikan Menengah. Jakarta: Kemendikbud.

Rahayu, Y, M. 2016. Pengaruh Perubahan Kurikulum 2013 Terhadap Perkembangan Peserta Didik. Jurnal Logika, XVIII (3), 2242. Retrieved from http://jurnal.unswagati.ac.id/index.php/logika /article/view/216

Ruja. I, N., \& Sukamto. 2015. Survey Permasalahan Implementasi Kurikulkum Nasional 2013 Mata Pelajaran Ilmu Pengetahuan Sosial Sekolah Menengah Pertama di Jawa Timur. Jurnal Sejarah Budaya dan Pengajarannya, 9 (2). Retrieved from

http://journal2.um.ac.id/index.php/sejarahdan-budaya/article/view/1540
Subkhan, K., \& Susilowati, S, M, E. 2015. Praktik Terbaik Pembelajaran IPA Sesuai Kurikulum 2013: Studi Kasus Sekolah Pilot SMP N 1 Magelang, 4(1). Retrieved from https://journal.unnes.ac.id/sju/index.php/ujbe /article/view/5235

Sugiyono. 2008. Metode Penelitian Kunatitatif Kualitatif dan $R \& D$. Bandung: Alfabeta

Sukmadinata, N, S. 2009. Metode Penelitian Pendidikan. Bandung: PT. Remaja Rosdakarya.

Supardi. 2012. Arah Pendidikan Di Indonesia dalam Tataran Kebijakan dan Implementasi. Jurnal Formatif, 2(2), 111-121, Retrieved from

https://journal.lppmunindra.ac.id/index.php/F ormatif/article/view/92/89

Sutama, Kristiawanto, \& Suyatmini 2016. Kontribusi Sarana Prasarana Pendidikan, Kondisi Lingkungan, Kedisiplinan Kerja Terhadap Kinerja Guru SD. Jurnal Manajemen Pendidikan, 11 (2), 91-102. Retrieved from http://jurnal.ums.ac.id/index.php/jmp/article/ view/2652

Sutjipto. 2014. Dampak Pengimplementasian Kurikulum 2013 Terhadap Performa Siswa Sekolah Menengah Pertama. Jurnal Pendidikan Dan Kebudyaan, 20 (2), 187199.

Setiadi, H. 2016. Pelaksanaan Penilaian Pada Kurikulum 2013. Jurnal Penelitian dan Evaluasi Pendidikan, 20 (2), 166-178. Retrieved from https://journal.uny.ac.id/index.php/jpep/articl e/view/7173 